\title{
Hematoma en riñón hidronefrótico
}

Carrión López P, Donate Moreno MJ, Pastor Navarro H, Giménez Bachs JM, Salinas Sánchez A, Virseda Rodríguez. JA.

Servicio de Urología. Hospital General Universitario. Albacete.

Actas Urol Esp. 2008; 32(5):672

$\mathrm{M}$ ujer de 68 años de edad, con antecedentes de HTA, que acude a Urgencias por presentar dolor en hemiabdomen izquierdo tras caída y contusión sobre dicha zona. A la exploración, la paciente se encuentra hemodinámicamente estable, presentando dolor a la palpación abdominal en hipocondrio izquierdo. Analíticamente destaca CR: 1,9, Hto: 52\%, y hematuria en el sedimento de orina. Se realiza TAC que informa de gran riñón izquierdo hidronefrótico con litiasis ureteral y colección perirrenal izquierda sugestiva de hematoma (Figs. 1, 2 y 3).

Tras 10 días de ingreso hospitalario y tratamiento conservador, habiendo precisado únicamente la transfusión de un concentrado de hematíes por descenso de Hto, se decide alta hospitalaria y cirugía diferida.

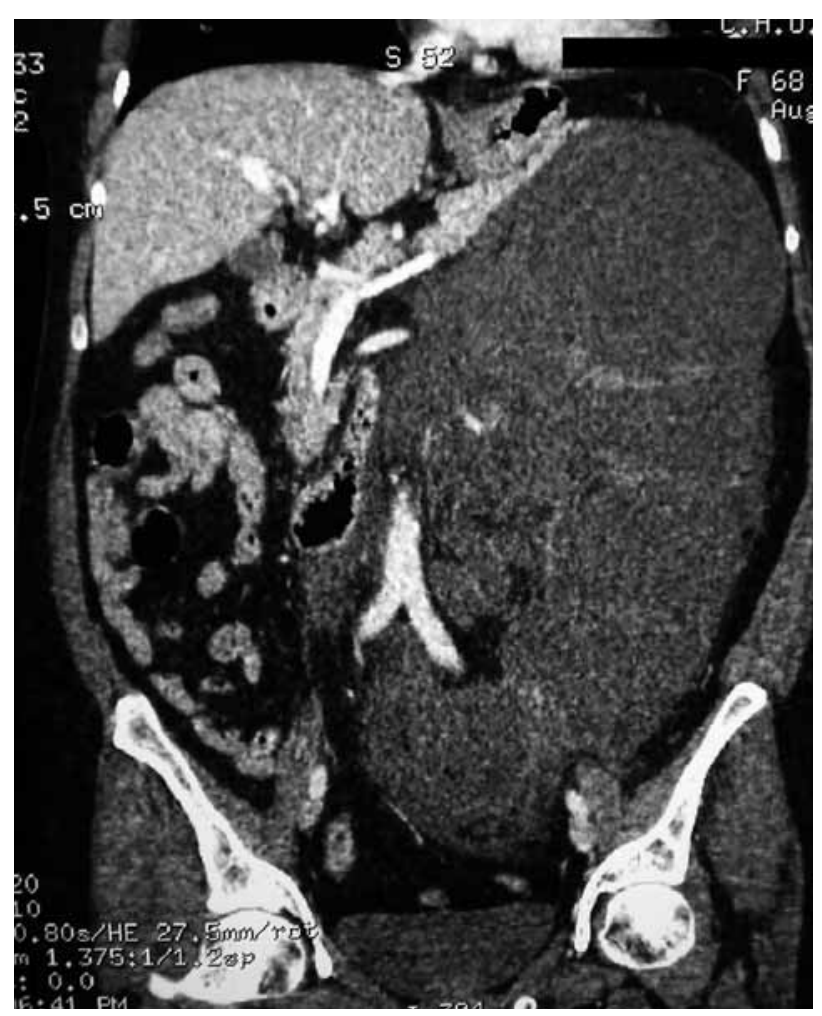

FIGURA 1

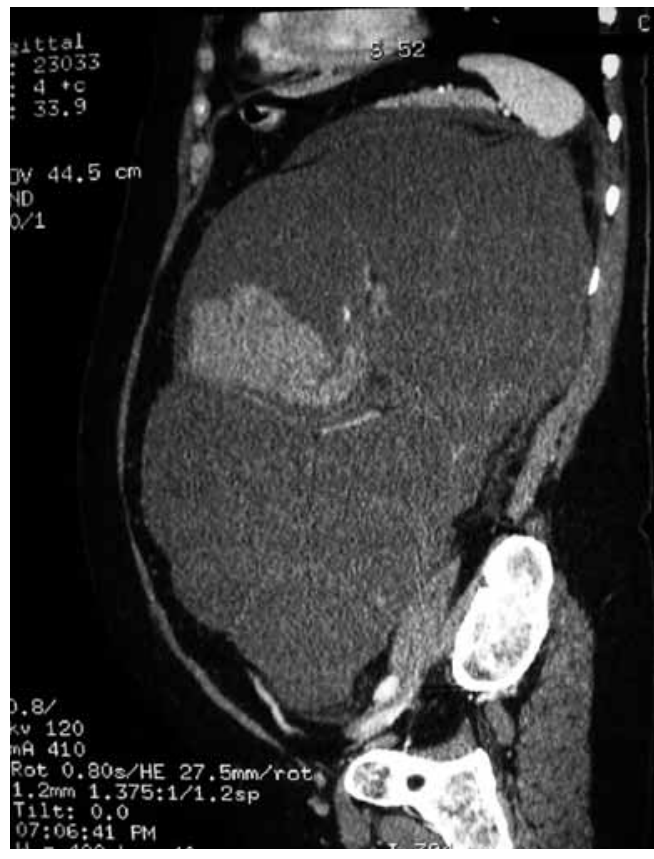

FIGURA 2

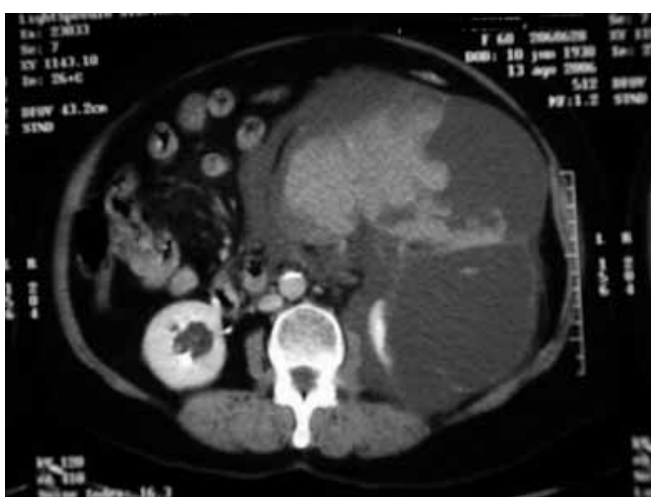

Un mes más tarde se practica Nefrectomía Izquierda por riñón hidronefrótico secundario a litiasis ureteral.

Correspondencia autor: Dr. P. Carrión López

Servicio de Urología. Hospital General Universitario de Albacete Hermanos Falcó, s/n - 02006 Albacete. Tel.: 967597100

E-mail autor: pedrocarrion1980@hotmail.com

Información artículo: Imágenes en Urología

Trabajo recibido: enero 2007

Trabajo aceptado: febrero 2007 